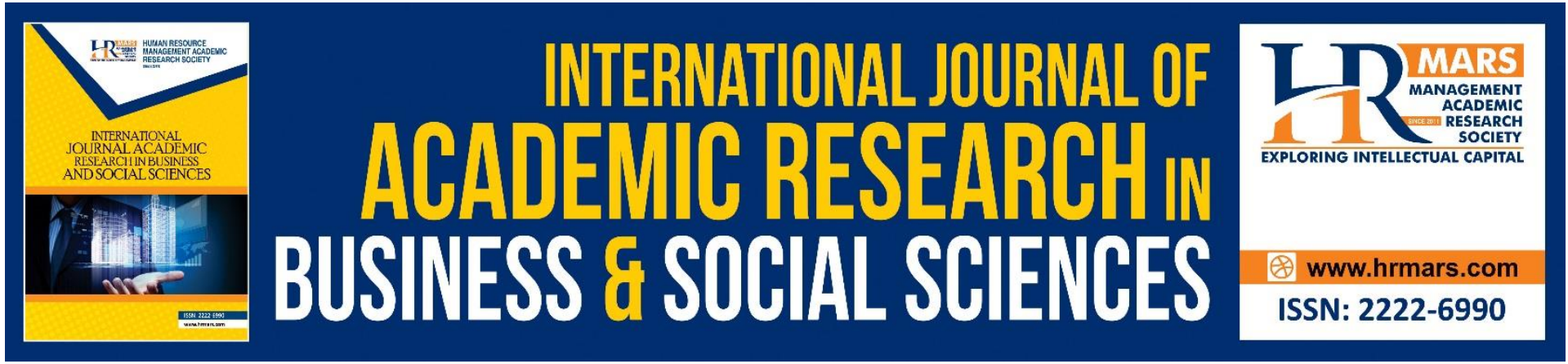

\title{
Epidemiology of Active Recreation Injuries Presenting to A Tertiary Sabah Parks in Kota Kinabalu Sabah
}

\author{
Alvin Raj A/L Santhanadass, Jaffry Bin Zakaria, Madya Gunathevan a/l \\ Elummai, Kumaran Gengatharan \& SP Subramaniam
}

To Link this Article: http://dx.doi.org/10.6007/IJARBSS/v11-i7/10440

DOI:10.6007/IJARBSS/v11-i7/10440

Received: 03 May 2021, Revised: 05 June 2021, Accepted: 26 June 2021

Published Online: 08 July 2021

In-Text Citation: (Santhanadass et al., 2021)

To Cite this Article: Santhanadass, A. R. A., Zakaria, J. Bin, Elummai, M. G. a/l, Gengatharan, K., \& Subramaniam, S. (2021). Epidemiology of Active Recreation Injuries Presenting to A Tertiary Sabah Parks in Kota Kinabalu Sabah. International Journal of Academic Research in Business and Social Sciences, 11(4), 292-302.

\section{Copyright: @ 2021 The Author(s)}

Published by Human Resource Management Academic Research Society (www.hrmars.com)

This article is published under the Creative Commons Attribution (CC BY 4.0) license. Anyone may reproduce, distribute, translate and create derivative works of this article (for both commercial and non-commercial purposes), subject to full attribution to the original publication and authors. The full terms of this license may be seen at: http://creativecommons.org/licences/by/4.0/legalcode

Vol. 11, No. 7, 2021, Pg. 292 - 302

Full Terms \& Conditions of access and use can be found at http://hrmars.com/index.php/pages/detail/publication-ethics 


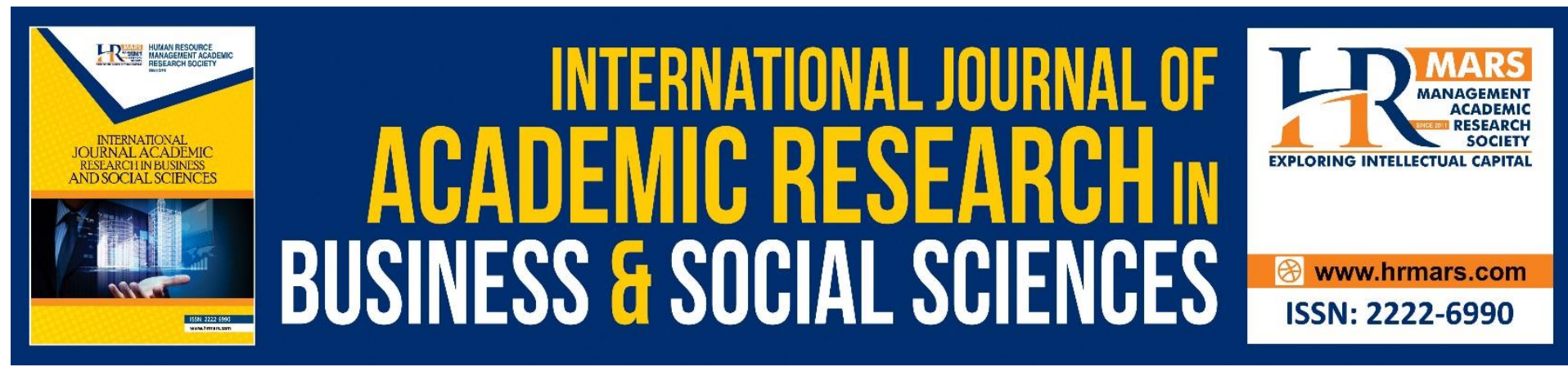

\title{
Epidemiology of Active Recreation Injuries Presenting to A Tertiary Sabah Parks in Kota Kinabalu Sabah
}

\author{
Alvin Raj A/L Santhanadass ${ }^{1}$, Dr. Jaffry Bin Zakaria², Prof \\ Madya Dr. Gunathevan a/l Elummai ${ }^{3}$, Kumaran Gengatharan ${ }^{4}$ \\ \& SP Subramaniam ${ }^{5}$ \\ ${ }^{1}$ Doctarate student, Faculty of Sports science and Coaching, University Pendidikan Sultan \\ Idris, Perak, Malaysia, ${ }^{2}$ Letrucer, Faculty of Sport science and Coaching, University \\ Pendidikan Sultan Idris, Perak, Malaysia, ${ }^{3}$ Associate Professor. Faculty of Sports science and \\ Coaching, University Pendidikan Sultan Idris, Perak, Malaysia, ${ }^{4}$ Doctarate student, Faculty of \\ Sports science and Coaching, University Pendidikan Sultan Idris, Perak, Malaysia, ${ }^{5}$ Doctarate \\ student, Faculty of Sports science and Coaching, University Pendidikan Sultan Idris, Perak, \\ Malaysia. \\ Email: alvin_rajj@yahoo.com
}

\begin{abstract}
Introduction: Sabah is unique due to a combination of sports and recreation with nature leads to the establishment of interesting places to visit and observe the beauty of flora and fauna. At the same time, sports and recreation should also be given due attention based on the safety of visitors and sports and recreation enthusiasts in Sabah. This is because reports related to sports and recreational activity injuries are increasing day by day and they become recurring issues. Due to the large number of visitors and sports enthusiasts, the statistics of injury reports in sports and recreation have never decreased. In the meantime, this study aims to look at the procedures of the safety aspects that have been complied and followed throughout as well as the types of injuries.

Methodology: A retrospective cross-sectional study of recreation in related injuries presented to the Sabah parks between 2018 till 2019. Data was extracted from the Sabah parks database and annual reports such as Demographics and injuries management details were extracted. Data were recorded and analysed using SPSS software.

Results: A total of 321 patients were identified among those who had suffered injuries over the past 3 years. In 2017 the highest injury case was caused by jelly fish which was $20.8 \%$, coral accident was $15.2 \%$ and falls while hiking and tracking was $13.6 \%$. While in 2018 there were $24.3 \%$ cases where the injuries and the cause of injuries couldn't be detected. Sprained cases were $23.4 \%$, and $17.76 \%$ cases of slip and fall while doing activities. In $2019,29.41 \%$ cases reported were caused by sprained injuries, followed by acute mountain sickness AMS, $21.17 \%$ cases and 15.29 sprained injuries reported.
\end{abstract}


Conclusion: Even though most of these injuries are not critical, most afflicted individuals seek medical care from the emergency unit, leading to excessive crowding and inappropriate use of the health care system. This shows the lack of self -risk management and the need to overcome this problem with a self-risk management module.

Keyword: Fatal And Non-Fatal Injuries, Recreation, Self-Risk Management

\section{Introduction}

Sports and recreation provide various advantages and benefits to all sports and recreation enthusiasts, especially those is Sabah, a land known for its diverse flora and fauna such as mountains, islands, rivers with strong currents and the sea. In fact, Sabah is one of the most visited states as local and international tourists throng the various natural attractions as well as sports and recreations it has to offer. Some of the most preferred sports and recreational activities in Sabah are mount Kinabalu climbing, rafting, cycling, wall-climbing, trekking, trailwalking, camping, jogging, marathons, scuba diving, paragliding and the list goes on.

The number of visitors to Kinabalu Park which involves those who were at various stations in Taman Kinabalu main headquarters in Kundasang, Poring Hot Spring station in Ranau, Serinsim Sub-station in Kota Marudu, Sub-station in Mesilau in Kundasang, Sayap SubStation at Kota Belud, Monggis Sub-Station in Ranau and Norther area of Kg. Nalapak SubStation was 611,624 in 2010 and 554,773 tourists were recorded in 2009. There was an increase of 56,851 tourists or $10 \%$ in 2010 as compared to the previous year. 489,840 Malaysians visited Kinabalu Park in 2010 and 446,211 tourists came in 2009. There was an increase of 43,629 local tourists or $10 \%$ compared to 2009 . As for international tourists, 121,784 visited Kinabalu Park in 2010 and 108,562 in 2009. An increase in the international tourists at 13,222 or $12 \%$ was recorded as compared to 2009, (Sabah Parks, 2010).)

The number of visitors to Tunku Abdul Rahman Park, which is inclusive of islands such as Manukan, Mamutik, Sapi and Gaya was 340,092 in 2010 and there were 297,706 visitors in 2009. There were an additional 42,386 tourists or $14 \%$ as compared to the amount in 2009 . In 2010, there were 149,008 Malaysians who visited Tunku Abdul Rahman Park and 134,111 visitors in 2009. An increase of local tourists at 14,897 or $11 \%$ was recorded if compared to 2009. As for foreign visitors, 191,084 visited Tunku Abdul Rahman Park in 2010 and 163,595 foreign visitors were recorded in 2009. The increase in foreign visitors was recorded at 27,489 or $16.8 \%$ compared to 2009 . The main destination for visitors to Tunku Abdul Rahman Park was Manukan island which showed $42.8 \%$ or 145,885 from the total number of visitors which came to the station in 2010, (Sabah Parks, 2010).

The number of visitors to Pulau Sipadan Park was 43,475 which marked a decrease of $0.18 \%$ or 78 individuals compared to the number in 2019 which was 43,553 visitors. 5,691 Malaysians had visited Pulau Sipadan Park in 2010 and there were 5,538 Malaysian visitors in 2009. The increase in number of Malaysian visitors was recorded higher with an additional number of 153 or $2.7 \%$ compared to 2009. In 2010, 37,784 foreign visitors came to Pulau Sipadan park and 38,015 visited the place in 2009. The decrease was 231 foreign visitors or $0.6 \%$ as compared to the number of visitors in 2009, (The board of trustees of the Sabah parks annual report, 2010).

The number of visitors to Banjaran Crocker Park which were obtained from various stations such as Keningau headquarters, Mahua Sub-station in Tambunan, Inobong Substation in Penampang and Melalap Sub-station in Tenom was 20,156 in 2010 and it was 16,946 in 2009. The number of visitors in 2010 increased with additional 3,210 visitors or $18.9 \%$. Altogether, there were 19,417 Malaysian visitors who went to Banjaran Crocker Park in 2010 
and there were only 16,496 Malaysian visitors in 2009. An increase of 2,921 Malaysian visitors or $18 \%$ was recorded as compared to the number in 2009 . There were 739 foreign visitors who came to Banjaran Crocker Park in 2010 and 450 foreign visitors in 2009. An increase of foreign visitors by 289 or $64 \%$ compared to the number of foreigners in 2009. The main destination for visitors to Banjaran Crocker Park was Mahua Sub-station at 83\% or 16,802 visitors from the total amount of visitors who came to the station in 2010, (The board of trustees of the Sabah parks annual report, 2010).

The number of Mount Kinabalu climbers in 2010 increased by $0.1 \%$ or 49 individuals as compared to the number of climbers in 2009. There was an increase in the number of Malaysian climbers at $2.9 \%$ or 569 individuals in 2010 compared to the number in 2009. However, the number of foreign climbers in 2010 has declined by $2 \%$ or 520 individuals as compared to the year before. Locals made the highest number of visitors to the parks around Sabah. 743,793 Malaysians had been to several parks in Sabah in 2010 and 673,043 visitors were recorded in 2009 . The increase of $10.5 \%$ or 70,750 visitors as compared to the number in 2009, (The board of trustees of the Sabah parks annual report, 2010).

These data proves that Sabah is a unique state that has succeeded in combining sports and recreations with nature which features interesting places to visit and exotic flora and fauna. Visitors as well as sports and recreation enthusiasts contributed to the state's income generation and at the same time, preservation of nature takes place as an indirect effect of sustaining tourism. Sports and recreational activities are given due attention based on the importance of safety those who participate in these activities. Reports indicated that there was an increase in injuries reported among the sports and recreation enthusiasts since there are a lot of them who participated in many activities. Hence, statistics shows that there is a continuous report as the matter keeps recurring. One of the reports came from Aduka (2016), which stated that two women were rescued by Gunung Kinabalu search and rescue team and Kinabalu Park rangers from leg cramps and muscle injury. The condition rendered them immobile and the women also suffered from Acute Mountain Sickness (AMS). Bernama (2019), reported that rescue team and MOSAR had to be carried down from Gunung Kinabalu peak since they had lost balance and hurt their legs. Moreover, based on report by Ruzaini (2018) a foreigner had to be carried down by MOSAR team because he sprained his ankle and could not walk. Ruzaini (2018) also reported a climber experienced short of breath while climbing the mountain due to Acute Mountain Sickness (AMS). Recqueal (2019) added that the Research and Rescue team (MOSAR), had to carry down a Belgium woman, who was hurt after she fell off while climbing Kinabalu mountain and Fardy (2019) reported a mishap which involved three divers and two tourists from China lost their lives while scuba diving.

Mass media reports showed that getting injured while being involved in sports and recreational activities were serious matters and they required more immediate attention. This predicament must be solved before it worsened as these unfortunate incidents could be the result of carelessness, the surroundings and equipment failure. Hence, this study is conducted to identify types of repeated accidents and injuries which were often suffered by visitors to Sabah parks.

In a study by Faulhaber et al (2020) the researcher investigated non-fatal accidents which caused serious injuries in climbing excursion and found that these mishaps were caused by lack of health-screening prior to the activity. For instance, climbers required visual test to ensure that they had clear vision before climbing to prevent them from falling or slipping while climbing. Suitable shoes are also requited to ensure balance and grip when there was friction with uneven or slippery surfaces. Furthermore, the weight carried by the climbers 
could cause pressure on muscles and joints especially the knees which had to sustain extra load and possibility of injury. Another contributing factor to injuries among mountain climbers was excessive Body Mass Index (BMI) which causes knee and muscle injuries. As a result of these injuries, climbers would suffer serious health issue and they would not be able to continue their activity. Hence, each mountain climber needs the right guidance and exposure prior to starting their journey climbing the perilous track to the top and avoid injuries.

Yang, Ibrahim, Jenarun, \& Liew, (2020) ;Mairer et al., (2010) highlighted that one of the factors of Acute Mountain Syndrome of AMS was the lack of mountain guide for Mount Kinabalu to lead the way to the top. Majority of the climbers were recreational climbers, so they did not have adequate information on and exposure to AMS. Therefore, they were more vulnerable to the risk of AMS compared to experienced climbers. Faulhaber, et al. (2017) generally stated that most accidents which caused injuries happened on the way down from the mountain or hill and this involved men. The researchers emphasized that self-evaluation on one's ability and preparation to face the risk while doing recreational activities is crucial to prevent unwanted incidents.

Ramanpong et al (2020) stated that $55.4 \%$ of the climbers were those who had history of health issues. They failed to conduct evaluation of individual risk-management which could have helped them to prevent unwanted incidents or prepare to each activity. With preparation, mountain climbers and recreation enthusiasts would be able to prevent any injury such as heart attack with symptoms such as chest pain and pressure and piercing pain in the chest. Individuals with high blood pressure might experience some symptoms such as headache, respiratory problems and syncope. In addition, diabetic patients suffered from fatigue. Sports and recreational activities are often exposed to the aspects of safety before, during and after these activities were carried out. Most accidents took place at recreational areas since there were many unsafe facilities, various physical abilities and the failure on the guard's part to monitor the area (Gul, 2018). As for Jamilah (2014) she stated that common measures were monitoring, maintenance and planning to prevent accidents and injuries. Eliminating the risk of accidents is next to impossible since most of them are unpredictable, but accidents can be prevented and reduced through efficient risk management (Burtscher, 2012).

- Parkhouse risk model which was introduced in 1990 is chosen as the basis for this research. This model emphasizes on systematic risk management through a checklist used in identifying the potential and dangerous risk that one must face. The introduction of policy or standard operation procedure (SOP) is an alternative for a method to manage risk. Based on this model, visitors who want to carry out activities at parks in Sabah must take precautions and avoid risks for themselves too. The objective of this study is to investigate and highlight the index of the recreation injury taken place in Sabah parks.

\section{Methodology}

Research design applied for this study is known as cross sectional study through retrospective method. Data used for this study were derived from Sabah parks from 2017 to 2019. Moreover, confidential data which have not been published before, are used in this research. Different types of injuries while carrying out activities were part of the data obtained and these data were analysed by using SPSS software. 
Findings

Table 1 Types of Accidents at Sabah Parks

\begin{tabular}{|l|c|c|c|c|c|c|c|c|c|c|c|c|c|c|}
\hline \multicolumn{10}{|c|}{2017} & \multicolumn{10}{|c|}{ TOTAL } & $\%$ \\
\hline & $\mathrm{J}$ & $\mathrm{F}$ & $\mathrm{M}$ & $\mathrm{A}$ & $\mathrm{M}$ & $\mathrm{J}$ & $\mathrm{J}$ & $\mathrm{A}$ & $\mathrm{S}$ & $\mathrm{O}$ & $\mathrm{N}$ & $\mathrm{D}$ & & \\
& $\mathrm{A}$ & $\mathrm{E}$ & $\mathrm{A}$ & $\mathrm{P}$ & $\mathrm{A}$ & $\mathrm{U}$ & $\mathrm{U}$ & $\mathrm{U}$ & $\mathrm{E}$ & $\mathrm{C}$ & $\mathrm{O}$ & $\mathrm{E}$ & & \\
& $\mathrm{N}$ & $\mathrm{B}$ & $\mathrm{R}$ & $\mathrm{R}$ & $\mathrm{Y}$ & $\mathrm{N}$ & $\mathrm{L}$ & $\mathrm{G}$ & $\mathrm{P}$ & $\mathrm{T}$ & $\mathrm{V}$ & $\mathrm{C}$ & & \\
\hline DEATH & & & & 1 & & & & & & & & & 1 & 0.85 \\
\hline SPRAINED INJURIES & 3 & 1 & 2 & 5 & & & & & 1 & & 1 & & 13 & 11.11 \\
\hline $\begin{array}{l}\text { CUTS AND BRUISES FROM A } \\
\text { SLIP/FALL }\end{array}$ & 1 & 4 & 3 & 1 & & & & 3 & 1 & 2 & 1 & 1 & 17 & 14.53 \\
\hline $\begin{array}{l}\text { ACCIDENTALLY STEP ON } \\
\text { POISONOUS FISH }\end{array}$ & 1 & & 1 & 2 & & & & & & & & & 4 & 3.41 \\
\hline ALMOST DROWNED & 1 & 3 & 1 & 1 & & & & & 5 & & 1 & 3 & 15 & 12.82 \\
\hline AMS & & & & & 2 & & & & & & & & 2 & 1.71 \\
\hline DROWNED (FATAL) & 3 & 1 & 4 & 1 & 9 & & 1 & 6 & 1 & & & & 26 & 22.22 \\
\hline JELLYFISH STING & & & 1 & 5 & 2 & 4 & 1 & 3 & 1 & & 1 & 1 & 19 & 16.23 \\
\hline CORAL ACCIDENT & 1 & 1 & & 1 & & & & 1 & & 1 & 1 & & 6 & 5.13 \\
\hline OTHERS & & & & & & & & & & & & & 117 & 99.98 \\
\hline $\begin{array}{l}\text { TOTAL MONTHLY REPORT } \\
\text { OF ACCIDENTS }\end{array}$ & & & & & & & & & & & & & & \\
\hline
\end{tabular}

Table 1.0 indicated types of accidents which happened in 2017 at Sabah parks: The highest number of accident cases in that year was recorded at 26 or $22.22 \%$ involving incidents of contact with jellyfish. The second highest number of accidents as Sabah Parks involved corals and 19 cases or $16.23 \%$ was recorded. In addition, the third highest number of cases, 17 or 14.53\% was recorded from cuts and bruises from visitors who fell or slipped while doing recreational activities at Sabah parks including climbing Mount Kinabalu. Next, incidents involving AMS or Acute Mountains Sickness was reported at 15 cases or $12.82 \%$. For visitors who were almost drowned, 14 cases or $11.97 \%$ was reported. There were 13 cases or $11.11 \%$ of the cases reported involved accidents that happened because of sprained injuries. Six cases or $5.13 \%$ involved various accidents which happened at Sabah parks. Cases such as accidentally stepped on poisonous fish was 4 or $3.41 \%$. 2 visitors or $1.71 \%$ drowned and fatal accident was 1 or $0.85 \%$. The total number of accident cases reported in 2018 was 117 and all these took place at Sabah parks. 
Table 2 Types of accidents in Sabah Parks

\begin{tabular}{|c|c|c|c|c|c|c|c|c|c|c|c|c|c|c|}
\hline \multicolumn{14}{|c|}{2018} & \\
\hline TYPES OF ACCIDENTS & \multicolumn{12}{|c|}{ MONTH } & TOTAL & $\%$ \\
\hline & $\mathrm{J}$ & $\mathrm{F}$ & $\mathrm{M}$ & $A$ & $M$ & $\mathrm{~J}$ & $\mathrm{~J}$ & A & $S$ & 0 & $\mathrm{~N}$ & $D$ & & \\
\hline & $A$ & $E$ & $A$ & $P$ & $A$ & $U$ & $U$ & U & $E$ & C & $\mathrm{O}$ & $E$ & & \\
\hline & $\mathrm{N}$ & B & $\mathrm{R}$ & $\mathrm{R}$ & Y & $\mathrm{N}$ & $\mathrm{L}$ & G & $\mathrm{P}$ & $\mathrm{T}$ & $\mathrm{V}$ & C & & \\
\hline DEATH & & & & & & & & & & & & & 0 & 0 \\
\hline SPRAINED INJURIES & & & 2 & 6 & 1 & 1 & 3 & 2 & 2 & 1 & 5 & 3 & 26 & 27.37 \\
\hline $\begin{array}{l}\text { CUTS AND BRUISES FROM A } \\
\text { SLIP/FALL }\end{array}$ & 1 & & 2 & 3 & & 4 & 2 & 1 & 1 & 1 & & 1 & 16 & 16.84 \\
\hline $\begin{array}{l}\text { ACCIDENTALLY STEP } \\
\text { POISONOUS FISH }\end{array}$ & & & & 1 & 1 & & & & 1 & & & & 3 & 3.16 \\
\hline ALMOST DROWNED & & & & & & & & & & & & 1 & 1 & 1.05 \\
\hline AMS & & 3 & 2 & 4 & 2 & 1 & 2 & 1 & & & & & 15 & 15.79 \\
\hline DROWNED (FATAL) & & & & & 1 & & & & & & & & 1 & 1.05 \\
\hline JELLYFISH STING & & 1 & & 3 & 2 & & & & & & & & 6 & 6.32 \\
\hline CORAL INJURIES & & 3 & 2 & 4 & 2 & 2 & 2 & 7 & 2 & & & 3 & 27 & 28.42 \\
\hline TOTAL & & & & & & & & & & & & & 95 & 83.16 \\
\hline
\end{tabular}

Table 2.0 indicates types of accidents which took place at Sabah parks in 2018. Some of the cases reported were, cases which were not listed, and the cause was unknown were 27 or 28.42\%: this figure was the highest in 2018. Sprained injuries had 26 cases or $27.37 \%$ which was the second highest number of cases reported. As for the third highest case was caused by cuts and bruises from a slip and fall at 16 cases or $16.84 \%$. Accidents related to AMS or Acute Mountains Sickness was recorded at 15 or $15.79 \%$ and cases involving contacts with jelly fish was marked at 6 or $6.32 \%$. In addition, there were 3 cases or $3.16 \%$ reported involving visitors who accidentally stepped on poisonous fish. Cases which involved visitors who nearly drowned and loss of life to drowning had only 1 case at $1.05 \%$. The total number of accidents reported at Sabah parks in 2018 was 95 cases. 
Table 3 Types of Accidents at Sabah Parks

\begin{tabular}{|c|c|c|c|c|c|c|c|c|c|c|c|c|c|c|}
\hline \multicolumn{14}{|c|}{2019} & \\
\hline TYPES OF ACCIDENTS & \multicolumn{12}{|c|}{ MONTH } & TOTAL & $\%$ \\
\hline & $\mathrm{J}$ & $\mathrm{F}$ & $M$ & $A$ & $M$ & $J$ & $\mathrm{~J}$ & $\mathrm{O}$ & $S$ & 0 & $\mathrm{~N}$ & $D$ & & \\
\hline & $A$ & $E$ & $A$ & $P$ & $E$ & $U$ & U & $\mathrm{G}$ & $E$ & K & 0 & I & & \\
\hline & $\mathrm{N}$ & B & C & $\mathrm{R}$ & 1 & $\mathrm{~N}$ & $\mathrm{~L}$ & $\mathrm{~S}$ & $\mathrm{P}$ & $\mathrm{T}$ & V & $\mathrm{S}$ & & \\
\hline DEATH & & & & & & & & & & & & & 0 & 0 \\
\hline SPRAINED INJURIES & 1 & 2 & 3 & 3 & & & 6 & 4 & 1 & 1 & & 4 & 25 & 37.31 \\
\hline $\begin{array}{l}\text { CUTS AND BRUISES FROM A } \\
\text { SLIP/FALL }\end{array}$ & & 1 & & 1 & & & 2 & 5 & 2 & 2 & & & 13 & 19.40 \\
\hline $\begin{array}{l}\text { ACCIDENTALLY STEP } \\
\text { POISONOUS FISH }\end{array}$ & & 1 & & & & & & & & & & & 1 & 1.49 \\
\hline ALMOST DROWNED & & & & 1 & & 1 & & & & & & & 2 & 2.99 \\
\hline AMS & 1 & 3 & 2 & 5 & & & 3 & 2 & 2 & & & & 18 & 26.87 \\
\hline DROWNED (FATAL) & & & & & & & & & & & & & 0 & 0 \\
\hline JELLYFISH STING & & & & & & & 1 & & & & & & 1 & 1.49 \\
\hline CORAL ACCIDENTS & & 1 & & & 1 & & 1 & 1 & & & & & 4 & 5.97 \\
\hline OTHERS & & 1 & & 2 & & & & & & & & & 3 & 4.48 \\
\hline MONTHLY TOTAL CASE & & & & & & & & & & & & & 67 & \\
\hline
\end{tabular}

Table 3.0 indicates the types of accidents which occurred at Sabah parks in 2019. There were 25 cases or $37.31 \%$ involving visitors who had sprained injuries which was the highest in 2019. The second highest number of cases was AMS or Acute Mountain Sickness at 18 cases or $26.87 \%$. The third highest cases were from cuts and bruises among visitors who slipped and fell while doing activities. There were also 4 cases or $5.97 \%$ reported for visitors who accidentally stepped on corals and for other types of accidents, there were 3 cases or $4.48 \%$. Moreover, there were 2 cases or $2.99 \%$ that represented almost drowned cases and there were 2 cases each: 1 case or $1.49 \%$ involved a visitor who accidentally stepped on poisonous fish and another 1 or 1.49 case was a visitor who was stung by jelly. Death and death caused by drowning were not reported this year. The total number of cases of accidents reported for 2019 at Sabah parks was 67 cases.

The most common cases reported in 2017, 2018 and 2019 from Sabah parks were cuts and bruises among visitors who fell and slipped while carrying out activities, sprained ankles, Acute Mountain Sickness (AMS), stung by jelly fish and stepped on corals as well as unknown accidents. Even though statistics indicated that there was a decline in the number of cases, repetitive incidents such as sprained ankle and cuts and bruises caused by falling and slipping while doing activities and AMS. This indicated that there was no drastic action yet by the authorities who were in charge of Sabah parks, to overcome the issues of accidents which kept on recurring every year.

\section{Discussion}

In this study, it was found that there were several factors which contributed to accidents such as age, one's physical state, alertness, carelessness, being panic, and lack of knowledge in the activities carried out (Faulhaber et al., 2020). Stanford et al. (2017) stated accident cases such 
as cuts and bruises from a slip and fall were caused by the lack of awareness, insufficient knowledge in the right techniques to carry out activities, inability to predict dangerous situations in their surroundings and unsuitable equipment. These influential factors were supported by Bowman \& Gossman, (2020) who stated that accidents in water happened when individuals involved paid less attention to dangers that lurk around them as they were engrossed in enjoying the activities. Israel, McCarthy, Rose, \& Rao, (2017); Weinbruch and Nordby, (2013); Burtscher (2012) agreed with these findings by emphasizing that some of the factors which must be given attention such as suitable equipment for an activity like climbing mount Kinabalu. A climber must wear the right shoe for mountain climbing and avoid common sports shoes. He also must conduct a research and obtain information about mountain climbing (Kinabalu) so that he could bring the right backpack, ensure that he has the right physical fitness and preparation to climb the mountain. In addition, a climber must bring his own medication and emergency equipment in case they are required. A medical check-up is also crucial to ensure the climber is healthy and is able to perform extreme activities. With the right preparation, the climber is able to avoid unwanted accidents.

Schreck, Weilbach \& Reitsma, (2020) obtained a significant finding when they introduced risk management to students who were involved in recreational activities. It was able to assist the students to overcome the issue of safety and act fast when faced with risky situations. Sunde \& Spano (2016); Moran (2008); Adeola (2004) also agreed that there has to be an explanation on self-assessment so that each individual who participates in activities must adhere to the procedures and understand the importance of his or her own safety. Only with such awareness and actions, everyone is able to take care of himself or herself and avoid any incident that might injure him or her. Hence, the person does not require orders from others to act in handling risks which he or she might have to face alone.

Knowledge in self risk management can increase the demand and interest among recreation practitioners as it will also be a boost to the tourism economy and career in sports and recreation. According to Sharp et al (2010) safety is an aspect that is part of an organization's "core value" in providing services to the end users. For those who are involved in extreme sports activities, they know that there are many risks to face but it is crucial to prioritize their own safety to avoid exposing themselves to too many risks (Fulbrook, 2017; Esfahani, 2014).

\section{Conclusion}

In order to ensure that all visitors to any park in Sabah is able to safely carry out interesting and fun activities, they need to be introduced to self-risk management module which will enable them to gain knowledge and steps to ensure their safety before attempting any activity. Each visitor is responsible for his or her own safety. By introducing the self-risk management to relevant parties, lives, money and time for treatment of injuries which took place at Sabah parks could be saved. Sabah park management will be able to bring down the number of repeated cases by educating each visitor on ways to ensure his or her safety as they participated in the activities there. As a result, the management will gain more trust as it can guarantee the visitor's safety.

\section{Reference}

Adeola, F. O. (2004). Environmentalism and risk perception: Empirical analysis of black and white differentials and convergence. Society \& Natural Resources, 17(10), 911-939. 
Aduka, J. S. (2016). Selamatkan dua pelancong cedera di hunung Kinabalu. Sabah Times. Retrieved from

http://www.newsabahtimes.com.my/nstweb/fullstory/8107Sabah Parks (2010). Annual report. The board of trustees of Sabah Parks

Bernama. (2019). Pendaki cedera diusung turun dari puncak Kinabalu. Sinar Harian. Retrieved from https://www.sinarharian.com.my

Bernama (2019). Pendaki warga Belgium cedera diusung turun dari puncak Kinabalu. Bernama. Retrieved from https://www.freemalaysiatoday.comBowman, J. C., \& Gossman, W. (2020). Diving Mask Squeeze. StatPearls [Internet].

Burtscher, M. (2012). Climbing the Himalayas more safely. BMJ , 344, e3778.

Esfahani, M. (2014). Factors influencing responsible behaviour related to safety and health on mountains: A case study of climbers on Mount Kinabalu, Malaysia (Doctoral dissertation, University of Malaya).

Fardy. B. (2019, Julai 5)Tiga penyelam termasuk dua pelancong china maut. Berita Harian. Retrieved from https://www.bharian.com.my

Faulhaber, M., Pocecco, E., Niedermeier, M., Ruedl, G., Walter, D., Sterr, R., ... \& Burtscher, M. (2017). Fall-related accidents among hikers in the Austrian Alps: A 9-year retrospective study. BMJ open sport \& exercise medicine, 3(1).

Faulhaber, M., Ruedl, G., Schneider, F., Walter, D., Sterr, R., Schobersberger, W., ... \& Pocecco, E. (2020). Characteristics of victims of fall-related accidents during mountain hiking. International journal of environmental research and public health, 17(3), 1115.

Fulbrook, J. (2017). Outdoor activities, negligence and the law. Routledge.

Israel, J. S., McCarthy, J. E., Rose, K. R., \& Rao, V. K. (2017). Watch Out for Wild Animals. Plastic and Reconstructive Surgery, 140(5), 1008-1022. doi:10.1097/prs.0000000000003754

Jamliah, A. (2014). MBPJ di rayu baiki kemudahan taman permainan. Utusan Malaysia, p. 3

Mairer, K., Wille, M., Bucher, T., \& Burtscher, M. (2009). Prevalence Of Acute Mountain Sickness In The Eastern Alps. High altitude medicine \& biology, 10(3), 239-245.

Fardy, B. (2018). Sesak nafas di Gunung Kinabalu. Metro. Retrieved from https://www.hmetro.com.myMoran, K. (2008). Re-thinking drowning risk: the role of water safety knowledge, attitudes and behaviours in the aquatic recreation of New Zealand youth: a thesis presented in fulfilment of the requirements for the degree of Doctor of Philosophy at Massey University, Palmerston North, New Zealand (Doctoral dissertation, Massey University).

Ramanpong, J., Yu, C. P., Chiang, P. N., \& Tsai, M. J. (2020). Risk management in suburban forest recreation areas: a retrospective analysis of illness cases. Urban Forestry \& Urban Greening, 126710.

Recqueal, R. (2019, September 7). Pendaki cedera diselamatkan. Berita harian. Retrieved from https://www.bharian.com.my

Richardson, G. D., \& Spano, S. J. (2018). Death on the dome: epidemiology of recreational deaths on Half Dome in Yosemite National Park. Wilderness Environ. Med. , 29, 338342

Ruzaini, Z. (2018). Pendaki Denmark terseliuh kaki diusung turun dari Gunung Kinabalu. AstroAwani. Retrieved from https://www.astroawani.com

Schreck, C. M., Weilbach, J. T., \& Reitsma, G. M. (2020). Improving graduate attributes by implementing an experiential learning teaching approach: A case study in recreation education. Journal of Hospitality, Leisure, Sport \& Tourism Education, 26, 100214. 
Sharp, L. A., Moorman, A. M., \& Claussen, C. L. (2010). Use of waivers and exculpatory clauses. Sport Law: A Managerial Approach.

Stanford, K. A., Phillips, L., Chang, Y., Leemon, D., Schimelpfenig, T., \& Harris, N. S. (2017). Trends in skin and soft tissue-related injuries in NOLS wilderness expeditions from 1984 to 2012. Wilderness \& Environmental Medicine, 28(4), 307-312.

Sunde, C. D., \& Spano, S. J. (2016). Wilderness Care of Acute Traumatic Wounds Curriculum. Trauma Cases Rev, 2, 039.

Parkhouse, B. L. (1996). The Management of Sport. 2nd.ed. United State: Mosby. Ms 164-183

Weinbruch, S., \& Nordby, K. C. (2013). Fatalities in high altitude mountaineering: A review of quantitative risk estimates. High Alt. Med. Biol. , 14, 346-359.

Yang, S. L., Ibrahim, N. A. F., Jenarun, G., \& Liew, H. B. (2020). Incidence and Determinants of Acute Mountain Sickness in Mount Kinabalu, Malaysia. High altitude medicine \& biology, 21(3), 265-272. 